\title{
A metodologia de Foucault no trato dos textos nietzschianos
}

\author{
Vânia Dutra de Azeredo*
}

\begin{abstract}
Resumo: Neste artigo analisaremos os textos de Foucault sobre Nietzsche: "Nietzsche, Freud e Marx" e "Nietzsche, a genealogia e a história" e os textos do filósofo acerca da História da sexualidade, volume I, visando mostrar que, no primeiro caso, o pensador francês procura atingir a precisão conceitual dos relatos nietzschianos a partir de uma leitura intratextual, no segundo, processa-se o tratamento de Nietzsche como instrumento de pensamento, fazendo com que Foucault se aproprie de Nietzsche para pensar as próprias questões filosóficas dele.

Palavras-chave: Nietzsche - metodologia - genealogia - história - sexualidade
\end{abstract}

Neste artigo, tencionamos mostrar, de uma parte, o método de Foucault no trato dos textos sobre Nietzsche como "Nietzsche, Freud e Marx" e "Nietzsche, a genealogia e a história" enquanto propõe-se à leitura de textos, à interpretação filosófica, em suma, a atingir a precisão conceitual dos relatos nietzschianos a partir de uma leitura intratextual. Todavia, em 1975, ele diz ter ficado mudo acerca do filósofo, levando-nos a perguntar: o que se processa de 1967 e 1971, quando Foucault falava sobre Nietzsche, para o emudecimento que se segue a 1975? O que se gesta entre um e outro momento no pensamento de Foucault? Consideramos que, por um

* Doutora em filosofia pela Universidade de São Paulo (USP), Brasil; Pós-doutora em filosofia pela École Normale Supérieure, França. Membro do Grupo de Estudos Nietzsche (GEN) e do Groupe International de Recherches sur Nietzsche (GIRN). E-mail: vd.azeredo@uol.com.br 
lado, processa-se o entendimento dele acerca do sentido referente ao pensamento de um filósofo, atestado pela afirmação que encontramos na entrevista a G. Barbedette. Referindo-se a Heidegger e a Nietzsche em 1984, Foucault diz: "Talvez eu escreva sobre eles algum dia, mas nesse momento eles apenas serão para mim instrumentos de pensamento".

Consideradas duas experiências fundamentais, Foucault entende Heidegger e Nietzsche como autores com os quais pensa e trabalha, embora sobre eles não escreva. Tendo lido mais Nietzsche do que Heidegger, a ele dedicou muitos cursos e os ensaios de 1967 e 1971. Em nossa avaliação, a eles se seguiu o silêncio do comentador para a gestação do filósofo através de uma mudança de método que abando na o trabalho de interpretação de textos. Por isso, o tratamento de Nietzsche como instrumento de pensamento. A partir de um dado momento, Foucault vale-se de Nietzsche para pensar as próprias questões filosóficas dele e, com isso, passa a realizar uma genealogia da moral, conforme afirmação a Brochier em 1975: "Se (...) fosse pretensioso, daria como título ao que faço: genealogia da moral".2. Mas ele se diz nietzschiano e contamos mostrar como se processa esse nietzschianismo que o atravessa:

sou simplesmente nietzschiano e tento, dentro do possível e sobre um certo número de pontos, verificar, com a ajuda dos textos de Nietzsche - mas também com as teses anti nietzschianas (que são igualmente nietzschianas!) - o que é possível fazer nesse ou naquele domínio ${ }^{3}$.

Foucault, notadamente no primeiro volume da trilogia destinada à história da sexualidade, apropria-se do discurso nietzschiano, ou, mais do que isso, vale-se do procedimento genealógico empreendido

1 FOUCAULT, M. Ditos e escritos. Trad. Elias Monteiro. 2 ed. Rio de Janeiro: Forense, 2005, V, p. 259.

2 Id. Ib., IV, p.174.

3 Id. Ib., V, p. 260.

58 I Cad. Nietzsche, São Paulo, v.I n.35, p. 57-85, 2014. 
por Nietzsche para desvelar a questão da sexualidade desde a inscrição discursiva dela. Em A vontade de saber, encontramos uma genuína genealogia da moral que vai ao encontro da afirmação de Foucault a J._J. Brochier de 1975, já citada por nós, acerca do seu fazer filosófico. Ora, ao relacionar as relações de saber e poder expressas nos discursos sobre a sexualidade, Foucault procede à busca da proveniência dela, do surgimento de cada consideração referente ao tema, de modo a apresentar seu processo de gravação e transformação avaliativa. Sexualidade como máscara, medicamento, veneno, diria Nietzsche. Mas é Foucault quem fala contando com o discurso nietzschiano. Convém notar que se trata do abandono do comentador para a emergência do intérprete e avaliador.

Comecemos por mostrar que Foucault preocupou-se, juntamente com Deleuze, com a edição das obras completas de Nietzsche, dado que a edição francesa dessa obra foi dirigida por Foucault e Deleuze inicialmente e, depois, por Deleuze e Maurice de Gandillac ${ }^{4}$. O que nos mostra a preocupação do pensador francês com a necessidade de critérios para a publicação dos textos e para a leitura do autor de Assim falava Zaratustra. Na introdução geral às Obras filosóficas completas de Nietzsche, lemos:

Desejamos que o novo dia, trazido pelos inéditos, seja o do retorno a Nietzsche. Desejamos que as notas que ele pôde deixar, com seus múltiplos planos, resgatem aos olhos dos leitores todas as suas possibilidades de combinação, de permutação, que contenham de agora para sempre, em matéria nietzschiana, o estado inacabado do "livro a advir".

Uma citação entre outras, datada de 1967, remete à preocupação do filósofo com os estudos de Nietzsche desde o rigor e fidelidade às

4 Cf. Id. Ib., II, p. 30.

5 Id. Ib., p. 39. Convém mencionar que essa introdução foi feita juntamente com G. Deleuze. 
intenções teóricas do filósofo na proposta de edição de sua obra, que venha, em definitivo, suplantar as distorções feitas por Elisabeth Forster, quando da publicação aleatória dos póstumos em A vontade de potência ${ }^{6}$, livro que não foi escrito por Nietzsche. Por outro lado, percebemos que tal rigor remete, também, a especificidade do texto nietzschiano ao ser observado por Foucault as múltiplas notas que ensejam, resgatam as possibilidades de leitura, de permuta e o livro inacabado a advir presentes nos textos de Nietzsche. Com isso, já em 1967, Foucault apontava para a condição singular desses textos. Para um modo diverso de leitura e compreensão filosófica introduzida por Nietzsche, mas ele já havia mencionado essa distinção em 1966 em entrevista a C. Jannoud: "Não é menos verdade que o surgimento de Nietzsche constitui um corte na história do pensamento ocidental. O modo do discurso filosófico mudou com ele" ${ }^{\text {. }}$. Reconhecia haver um antes e um depois de Nietzsche assinalado pela ruptura com um Eu anônimo, o que pode nos remeter a afirmação do filósofo alemão que atravessa toda sua obra: "De tudo o que se escreve, aprecio somente o que alguém escreve com seu próprio sangue. Escreve com sangue; e aprenderás que o sangue é o espírito" (Za/ZA I, Do ler e do escrever, KSA 4.48).

De certa forma, a filosofia de Foucault busca o filosofar de Nietzsche, imbuir-se do discurso dele o aplicando às leituras que o pensador francês faz da literatura, da história e da política, acrescente-se as da loucura e da sexualidade. Enfim, não busca Foucault também a filosofia em tudo? Não estaria o silencia ou

6 Cf. FOUCAULT, M. Ditos e escritos. Trad. Elias Monteiro. 2 ed. Rio de Janeiro: Forense, 2005, II, p. 36. No texto lemos: “A obra de Nietzsche é brutalmente interrompida pela loucura, no início de 1889. Sua irmã, Elisabeth, se fez guardiã autoritária da obra e da memória. Ela faz publicar um certo número de notas póstumas. Os críticos lhe reprovam talvez menos as falsificações (as únicas que são evidentes se referem às cartas) do que as deformações: ela afiançou a imagem de um Nietzsche anti-semita e precursor do nazismo - o anti-Nietzsche por excelência".

7 Id. Ib., II, p. 32. À guisa de esclarecimento, pautamos nossa investigação nas entrevistas e nos textos publicados por Foucault acerca de Nietzsche desde a genealogia, sem mencionar os textos arqueológicos desse autor.

60 I Cad. Nietzsche, São Paulo, v.I n.35, p. 57-85, 2014. 
a mudez de 1975, alusiva a Nietzsche, transposta para um fazer nietzschiano? Afinal, guardada a pretensão, Foucault diz fazer uma genealogia da moral.

Nesse momento, vamos apresentar a leitura de Foucault de Nietzsche apresentada em julho de 1967 no Colóquio de Royaumont como aquele que inaugura uma nova hermenêutica. Trata-se de expor a análise do filósofo francês realizada em "Nietzsche, Freud e Marx" como aqueles que procedem à reviravolta em termos de interpretação, iniciando um momento novo e diferenciado na condução dos discursos. No referido texto, Foucault apresenta Nietzsche como inaugurando, juntamente com Freud e Marx uma nova hermenêutica.

Consideremos que, as análises da linguagem remetem, via de regra, ao signo, enquanto unidade básica de um sistema linguístico e, nesses termos, objeto de investigação da semiologia. Não obstante, o signo pode não comportar o acréscimo de predicativos desse tipo - unidade básica enquanto referente da interpretação - o que remete à própria linguagem, tomada agora como fluxo instituinte, a outra dimensão. Nesse sentido, põem-se em xeque a relação signo/significado e os correlatos ícone, indicador, ou índice ou símbolo. Querendo assinalar certa fragilidade existente na pressuposição básica de que a análise do signo remeteria ao significado e, com isso, a uma explicitação de sentidos possíveis. Isso requereria, de per si, situar a interpretação em um domínio fixo, pelo menos em termos daquilo que introduz a significação, no caso, o signo. Ora, se de um lado, essa atitude permitiria o resgate do conteúdo semântico da tradição e, desse modo, de toda carga de significação construída no decurso da história da civilização ocidental, de outro, poderia induzir a equívocos grotescos, uma vez que o signo, ao invés de preceder ou assentar a significação, poderia ser o seu resultado. Mas, adentrar nessa questão requer, como procedimento inicial, que se tematize as dimensões que situam a interpretação e, assim, a relação intérprete/interpretação a partir das próprias técnicas de interpretação. 
Parece ter sido essa a intenção de M. Foucault ao apresentar, nos Cahiers de Royaumont, Nietzsche, Freud e Marx como aqueles que remetem a interpretação a uma nova possibilidade e, com isso, instituem novamente a hermenêutica. Foucault principia sua análise acerca da interpretação, apresentando duas suspeitas que a linguagem suscita em nossa cultura: "a de que a linguagem não diz exatamente o que diz" e a de que "a linguagem ultrapassa de alguma maneira sua forma verbal"s.

Haveria um discurso essencial que subjaz às palavras e que, todavia, enquanto latente nem sempre é apreendido, inobstante manifestar-se. Daí ser necessária uma virada em termos de atitude interpretativa. Embora admitindo que cada forma cultural tenha um dado sistema de interpretação, em termos de técnicas e métodos, os mesmo, até o século XIX, apresentavam noções definidas. Em especial,Foucault toma comoexemploo séculoXVI, cujademarcação em termos de unidade mínima e lugar geral da interpretação é a noção de semelhança, possibilitando decifrar aquilo que foi dito. Aos séculos XVII e XVIII coube justamente colocar em suspenso essa noção e, com ela, os postulados do conhecimento anterior. Foi, contudo, no século XIX que se introduziu uma cisão radical em termos da substituição de noções que permitiriam a compreensão daquilo que se diz, através de um redimensionamento da própria interpretação: "nós nos interpretamos por essas técnicas". Isso porque com Nietzsche, Marx e Freud não houve uma substituição de signos, ou o estabelecimento de outros sentidos, mas destituição do signo qualquer unicidade e fixidez e, com isso, eles "transformaram a natureza do signo e modificaram o modo com que o signo em geral podia ser interpretado"10. O que transparece nesses autores é a recusa peremptória de uma interpretação instituinte a partir do signo, pois os signos antes mesmo de poderem ser oferecidos como

8 Id., ibid., II, p. 40.

9 Id., p. 41.

10 Id.

62 | Cad. Nietzsche, São Paulo, v.I n.35, p. 57-85, 2014. 
elementos para uma interpretação são eles mesmos já interpretação. A interpretação é tomada assim como "tarefa infinita". Ela não pode acabar, posto que não há um fato originário que detenha o sentido. Isso transforma o signo, uma vez que lhe retira o predicativo de unicidade e acresce-lhe o de "abertura irredutível", o que gera o inacabamento da interpretação que, segundo Foucault, se encontra expresso analogamente em Marx, Nietzsche e Freud. É a recusa do fato em favor da interpretação, "o inacabamento da interpretação, o fato de que ela seja sempre dilacerada e que ela permaneça em suspenso nos seus próprios limites..."11.

Esse inacabamento constitutivo da atitude interpretativa assenta no dado de que em não havendo algo a ser interpretado, pois que tudo é sempre interpretação, a mesma não pode atingir um estado terminal. "Cada signo é em si mesmo não a coisa que sofre a interpretação, mas a interpretação de outros signos" "12. Destituindo, assim, os lugares fixos do interpretandum e do interpretans, posto serem agora, intercambiáveis, dos quais se exclui a passividade e passa-se a atribuir a violência, o inacabamento e a infinitude. Daí uma impossibilidade congênita de paridade entre a semiologia e a hermenêutica, uma vez que a semiologia, ao crer na existência absoluta do signo, retira da interpretação seus pressupostos básicos. Convém mencionar que nossa leitura é, sem sombra de dúvida, tributária da foucaultiana no que tange à afirmação de que, em Nietzsche, não há nada a interpretar porque tudo é interpretação.

Em outro texto de 1971, Foucault detém-se a investigar o papel da genealogia nietzschiana com relação à história. Analisando o sentido dos termos origem (Ursprung), proveniência (Herkunft), ascendência (Abkunft), nascimento (Geburt) e surgimento (Entestehung) procura mostrar em que a genealogia de Nietzsche rompe com a pesquisa da história desde a origem e passa a situá-la

11 Id., p. 49.

12 Id., p. 189. 
no nível da proveniência, já que "tem o cuidado de escutar a história em vez de crer na metafísica"13. Tal afirmação de Foucault nos remete a uma diferença de procedimento evidenciado pela distinção entre o ato de escutar e o de crer. No primeiro caso, trata-se de deixar falar o longo texto difícil de decifrar do passado humano, supõe a atitude de abertura ao diverso, ao descontínuo, ao novo e inusitado que se oculta nos documentos do passado. No segundo, uma fixação do dado, um culto ao existente, mais do que interrogação, submissão ao previamente postulado, e, porque não dizer, mera atitude de adesão ao que se afirma através da crença inabalável e inquebrantável diante do posto. Veríamos como a atitude do camelo que Nietzsche apresenta em Assim falava Zaratustra nas metamorfoses do espírito. Voltaremos a elas posteriormente.

Nesse momento, queremos investigar a leitura que Foucault realiza da genealogia nietzschiana e, por isso, exporemos a primeira característica que dela ele apresenta: "1) A genealogia é cinzenta; ela é meticulosa e pacientemente documentária. Trabalha com pergaminhos embaralhados, riscados, muitas vezes reescritos" 14 . Como não assinalar a fidedignidade da exposição, atestada pelas afirmações de Nietzsche em Para a genealogia da moral. Lembremos que o filósofo alemão critica a investigação inglesa pela falta de documentação. As análises empreendidas anteriormente por alguns estudiosos da moral tendiam, na visão nietzschiana, desde o seu início, à futilidade, devido, basicamente, à superficialidade que norteava suas investigações referentes à moral. Essas análises foram pautadas por um procedimento totalmente a-histórico, o que, por si mesmo, impossibilita uma imparcialidade, visto que tais construções não poderiam demonstrar suas afirmações sem uma referência ao próprio passado da humanidade, à história da moralidade. Por essa razão, Nietzsche faz uma alusão às cores azul e cinza.

13 Id., II, p 262.

14 Id. Ib., p. 260.

64 I Cad. Nietzsche, São Paulo, v.I n.35, p. 57-85, 2014. 
De um lado, estariam as hipóteses inglesas, que se perdem no azul, falta de documentação e, portanto, de comprovação; de outro, o cinza, cor do genealogista, que busca na verificação do passado da humanidade o modo de construção da moralidade.

A exposição de Foucault vai ao encontro das afirmações presentes em Para a genealogia da moral, ao apontar para a minúcia do saber, da obstinação na erudição. Por isso, a genealogia, na visão do pensador francês, não se opõe à história, mas caminha com ela. A oposição se dá ao homem da ciência, à busca de significações ideais e teleológicas. No limite, encontramos como elemento de ruptura entre a genealogia e a ciência a pesquisa da origem. Observe-se que quando Nietzsche utiliza em seu discurso a palavra "origem", não designa uma proveniência atemporal de validade incondicional, mas justamente remete a uma postulação de sentido, ao estabelecimento de um valor, que, quando referida à origem, quer significar: Quem cunhou determinado valor? e se o fez, a partir de quê? que valor ele tem? Por isso, Foucault diz em "Nietzsche, genealogia e história", que o termo apropriado por Nietzsche é proveniência (Herkunft) e não origem (Ursprung).

A pesquisa da origem (Ursprung) remete a Platão e à história da filosofia enquanto busca obstinada pelo fundamento da moral. Para Foucault, no prefácio de Para a genealogia da moral, Nietzsche joga com os termos origem e proveniência para enfatizar a nítida oposição entre os termos, mesmo que, no final do texto, retorne a uma utilização neutra dessas palavras. Mas o mais importante para o pensador francês é apontar e perceber no discurso filosófico de Nietzsche a recusa da essência, já que a própria história ensinaria a rir da busca originária. Em sua afirmação: "O que se encontra no começo histórico das coisas não é a identidade ainda preservada de sua origem - é a discórdia entre as coisas, o disparate" ${ }^{15}$. Por isso,

15 Id. Ib., II, p 263. 
na avaliação dele, os termos proveniência (Herkunft) e surgimento (Entestehung) apontam de forma mais precisa ao sentido da genealogia do que origem (Ursprung).

Mas voltemos às especificações de proveniência (Herkunft) no sentido de compreender o discurso de Nietzsche desde a seleção de termos minuciosamente investigada por Foucault. "Herkunft: é o tronco, a proveniência; a antiga pertinência a um grupo - o do sangue, da tradição, o que liga aqueles da mesma altura ou da mesma baixeza"16. É o descobrimento das marcas impressas sutilmente e singularmete, que remetem menos a características genéricas do que ao entrecruzamento de marcas, impressões formadoras de uma rede, via de regra, embaralhada. Possibilita desvelar um conceito através dos acontecimentos díspares que o formaram. Daí Foucault remeter à exterioridade do acidente em sentido bem diverso da busca da verdade e do ser, já que remete à heterogeneidade de tudo.

Em nossa avaliação, encontramos essa exposição foucaultiana presente em Para a genealogia da moral quando Nietzsche exclui o vínculo existente entre a origem do juízo bom e aqueles aos quais o bem era feito, assim como da relação de igualdade entre bom e útil, demandando um novo caminho para seu estabelecimento. Surge, assim, a hipótese de que o juízo bom proviria daqueles que se sentiam como bons, isto é, justamente de homens distintos, poderosos e superiores, que julgavam como boas suas ações sem pensar na utilidade das mesmas, mas com o intuito de diferenciar o seu ser, mais do que o seu fazer, de um ser e fazer baixo e vulgar. Nesse sentido, há uma estreita ligação entre o sentir-se bom e a correspondente avaliação daquilo que seria bom, enquanto produção desses mesmos homens. É mister assinalar que o juízo bom não é afirmado como algo que possa valer em si, mas tão somente como algo postulado a partir de um si. O juízo ruim era estabelecido por esses mesmos

16 Id. Ib., p. 265. 
homens para designar o homem baixo, vulgar, e seu respectivo fazer. $\mathrm{O}$ deslizamento do termo ruim para o homem vulgar não era mais do que decorrência da oposição ao seu modo de ser nobre e superior.

A afirmação da superioridade como elemento denotador implica, necessariamente, uma ligação entre o sentimento e o valor, uma vez que a própria superioridade não provém de uma designação externa, mas primordialmente de um impulso interno. Logo, a referência nietzschiana ao "pathos da distância" como o lugar que possibilita criar valores. $\mathrm{O}$ termo lugar, utilizado aqui, quer simplesmente referendar a distinção entre uma exterioridade que sofre e uma interioridade que sente e, por isso, produz. Não cria a partir do externo, mas justamente do sentimento interior de "uma espécie superior de senhor, posta em proporção com uma espécie inferior, com um 'abaixo' - essa é a origem da oposição 'bom' e 'ruim". ${ }^{17}$ A interioridade constrói a exterioridade pelo estabelecimento de valores, enquanto expressão da avaliação e, portanto, da interioridade. Ora, caso se afirme que a avaliação se configura como expressão de um sentimento interior de distância e superioridade, enfim, de diferença com relação ao outro, ou aos outros, então, consequentemente, não pode haver relação entre a ação e a utilidade. Inclusive o estabelecimento dessa implicação, em Nietzsche, fica determinado somente pelo instinto de rebanho, cuja oposição diametral ao senhor se estabelece pela afirmação de um sentimento de identidade e igualdade entre os homens. Sentimento esse que, de um lado, cria uma distância intransponível com relação ao senhor e, de outro, justifica a ligação do bom a ações não egoístas favorecedoras da coletividade.

Para que a hipótese relativa à designação do bom como proveniente dos bons não se dirima no azul, próprio dos ingleses, Nietzsche procede a um estudo da proveniência desse juízo através da etimologia. Constata que em todas as línguas a palavra

17 Id. ibidem. 
"bom" deriva de uma mesma transformação conceptual. Encontra a palavra "nobre" (vornehm), no sentido de ordem social, como conceito-chave, através do qual se chega a idéia bom (gut), no sentido de privilegiado quanto à alma e, em paralelo, encontra as transformações das idéias de vulgar (gemein), plebeu (pöbelhaft), baixo (niedrig) como desenvolvendo-se até a idéia de ruim (schlecht). Nesse momento, ruim tem apenas a significação de simples, comum, diferente do senhor. Existem apenas elementos distintivos de castas. A Nietzsche importa observar que através das palavras e raízes que significavam "bom", transparece o matiz principal pelo qual os nobres se afirmavam como uma classe superior.

Em nossa avaliação, o texto de Foucault "Nietzsche, a genealogia, a história" encontra sua tese acerca da distinção dos termos origem (Ursprung), proveniência (Herkunft), ascendência (Abkunft), nascimento (Geburt) e surgimento (Entestehung) no texto Para a genealogia da moral, consistindo a leitura dele em uma análise detalhada das palavras e expressões enquanto remetem a um ou outro sentido. Em vista disso, o texto de 1971, como o de 1967 remeterem a uma investigação intratextual da obra de Nietzsche. Nesse momento da trajetória filosófica de Foucault, ele não emudece diante de Nietzsche, mas professa seu discurso através da investigação. $\mathrm{O}$ mesmo se dá quando relaciona a proveniência ao corpo e a tudo que diz respeito ao corpo. Ao introduzir o primado do corpo em Nietzsche, desde a pesquisa sobre a proveniência na genealogia, Foucault relaciona história e corpo na investigação genealógica nietzschiana: "A genealogia, como análise da proveniência, está, portanto, na articulação do corpo com a história." ${ }^{18}$.

Em $A$ vontade de saber vemos que ela principia com uma suspeita alusiva à repressão do sexo como expressão de sua história, mas não no sentido de refutá-la ou de falseá-la, mas, justamente, querendo situá-la nos discursos sobre o sexo nas sociedades

18 Id., Ib., p. 267.

68 I Cad. Nietzsche, São Paulo, v.I n.35, p. 57-85, 2014. 
modernas desde o século XVII ${ }^{19}$ de modo a entender o sentido e o valor postulados no devir dele. Recorre, para tanto, ao documento registrado, ou, nas palavras de Nietzsche, ao longo texto difícil de decifrar do passado moral humano. Como decifrador de hieróglifos, Foucault desce as profundezas de cada gestação discursiva visando a mostrar sem processo de surgimento e modificação. Daí ele recorrer a textos de 1769, Élément généraux de Police, de 1854, Pratique des confesseurs e de 1857, Étude médico-légale sur les attentas aux moeurs, aos documentos do Concílio de Trento, por exemplo, entre muitos outros. Por que recorremos às referências bibliográficas de Foucault? O que ensejamos com tal procedimento? Ora, mais do que expor as teses foucaultianas sobre a sexualidade, queremos mostrar o nietzschianismo de Foucault presente no seu discurso filosófico desde a e, particularmente, em A vontade de saber. Foucault genealogista prefere, bem como Nietzsche, o cinza, isto é, o documento havido, os registros passados, o longo texto hieroglífico difícil de decifrar do passado moral humano. É neles que vai encontrar o que foi dito sobre o sexo a partir do século XVII e, nesse sentido, proceder à revisão ou à resignificação da hipótese de repressão.

A partir de três questões, uma história, outra histórico-teórica e uma terceira histórico-política, Foucault dirige-se à crença na "hipótese repressiva". Em termos históricos, vem à tona a necessidade de evidência sobre a repressão do sexo. Afinal, elas existem? De modo histórico-teórico, entra em cena a pergunta pela mecânica do poder enquanto sendo ou não de ordem essencialmente repressiva. Por fim, mas, em certo sentido, por entremeios, a indagação históricopolítica requer a avaliação do discurso, pois ao relacionar repressão e poder indaga pelo seu funcionamento sem contestação ou pela denúncia e disfarce simultâneos. Munido de suspeitas, Foucault

19 Cf. FOUCAULT. História da sexualidade: a vontade de saber. Trad. Maria Thereza Albuquerque e J. A. Albuquerque, 15 ed. Rio de Janeiro: Graal, 2003, p. 15-16. 
pode enunciar a questão que o move e que constituirá o pano de fundo de sua genealogia da moral. Enunciemo-la: "Em suma, trata-se de determinar, em seu funcionamento e em suas razões de ser, o regime de poder - saber - prazer que sustenta, entre nós, o discurso sobre a sexualidade humana" ${ }^{20}$. Lembrando o aspecto fundamental que rege a genealogia do pensador francês como a identificação da vontade de saber que sustenta e instrumentaliza esse ou aquele discurso sobre o sexo. Em vista disso, a verdade ou a mentira acerca dele serem, de per si, irrelevantes. O que conta é a vontade de saber que move a verdade ou a mentira de um discurso. Nisso o filósofo francês detém-se enquanto genealogista da moral.

Foucault, como Nietzsche, admite a inverdade como condição da vida e, em vista disso, podemos dizes que a filosofia dele, como a do mestre Nietzsche, situa-se para além de bem e mal. O que conta, em ambos os pensadores, é a vontade que se manifesta em cada formação discursiva e que, no limite, expressa e revela o modo de ser daquele(s) que avalia(m), exposto(s), gradativamente, na leitura de um discurso, na combinação de forças nele presentes, nas lutas dele geradoras. Isso que está em caso na vontade de saber. Continuemos com as comparações, do mesmo modo que Nietzsche, Foucault rejeita a unicidade do conceito e do fato originário e recusa a vigência de uma unidade subjetiva como regente através de um sujeito fundante do ser, do conhecer e do agir. Há uma recusa do fundamento enquanto rejeição de significados prévios e a afirmação de verdades e de mentiras postuladas pela vontade de saber. A genealogia foucaltiana, seguindo de perto a de Nietzsche, detém-se no conhecimento da criação e das condições de criação das formações discursivas e, ao fazê-lo, traz a tona o valor delas; mesmo que a palavra valor não seja usada pelo discípulo na aplicação dos procedimentos do mestre. Observe-se o texto de Foucault:

$20 I d .$, Ib., p. 16.

70 I Cad. Nietzsche, São Paulo, v.I n.35, p. 57-85, 2014. 
buscar as instâncias de produção discursiva (que, evidentemente, também organizam silêncios), de produção de poder (que algumas vezes tem a função de interditar), das produções de saber (as quais, frequentemente, fazem circular erros ou desconhecimentos sistemáticos); gostaria de fazer a história dessas instâncias e de suas transformações ${ }^{21}$.

Com relação à história da sexualidade, Foucault a apresenta desde $\mathrm{o}$ as transformações que se processaram nas sociedades modernas, Trata-se de verificar o quanto o empreendimento foucaultiano é, simultaneamente, tributário e apropriador do procedimento de Nietzsche. Tributário, porque reconhece que Nietzsche lhe forneceu os instrumentos de pensamento; apropriador, porque se vale dos mesmos procedimentos nietzschianos para empreender uma genealogia da moral. A nosso ver, Foucault imbuiu-se da atmosfera gerada pelas noções do autor de Assim falava Zaratustra para dirigir o olhar à sexualidade. Por um lado, isso requereu o conhecimento dos conceitos com os quais o filósofo investiga. Supôs o ingresso na sua própria filosofia, o andar com, a intratextualidade como dimensão imperante que permite discorrer sobre um autor. De outro, requereu o distanciamento enquanto posição que permitiu pensar com Nietzsche sem pensar como Nietzsche. Dá-se, propriamente, o nascimento do genealogista francês mediante o tratamento do filósofo alemão como instrumento de pensamento. Daí a história da sexualidade enquanto genealogia da moral.

Em A vontade de saber, encontramos que, segundo a hipótese repressiva, no século XVII iniciaria uma repressão das sociedades burguesas, da qual não teríamos nos libertado. É o momento em que se torna mais custoso denominar o sexo ${ }^{22}$ mediante o controle da circulação dele na linguagem, embora ele tenha sido reduzido

21 Id., Ib., p. 17.

22 Cf. FOUCAULT, op. cit., p. 21. 
ao nível da linguagem para viabilizar a extinção das palavras que o vivificam. Nas palavras de Foucault: "mutismos que, de tanto calar-se, impõe o silêncio. Censura" ${ }^{23}$. Todavia, na ótica de Foucault, a observação das transformações que ocorreram nos três últimos séculos revela não o mutismo concernente ao sexo, mas o que o autor denomina explosão discursiva, mesmo com os controles sobre os enunciados da época clássica. Por isso, ele aponta para uma inversão fenomênica no nível dos discursos bem como dos seus domínios, uma vez que houve uma proliferação de discursos a partir do século XVIII.

Partindo do Concílio de Trento, Foucault aponta para a evolução da pastoral católica e do sacramento da confissão. A Contra-Reforma como eficaz no processo de acelerar a confissão anual, fazendo com que tudo seja dito, de modo a reter o sexo em um discurso que não permite ocultações. Formado em uma tradição ascética e monástica, o projeto de "colocação do sexo em discurso" ${ }^{24}$ estende-se para todos. "A pastoral cristã inscreveu, como dever fundamental, a tarefa de fazer passar tudo que se relaciona com o sexo pelo crivo interminável da palavra"25, cujo objetivo era tornar moralmente aceitável e útil. Eis, para Foucault, a grande sujeição que se processa. Assim, não há propriamente uma censura sobre o sexo, mas, diferentemente, uma promoção discursiva dele. Principalmente no século XVIII, nasce um discurso racional sobre o sexo, explicitado nas pesquisas quantitativas ou causais que dele fazem. Fala-se do sexo, mas não se tem uma teoria da sexualidade, ao invés disso, ela aparece de modo analítico, contábil e classificatório. É o funcionamento e a administração que vige. Foucault vê nisso que os discursos se articulam desde um feixe de relações de poder.

Ao final das considerações acerca da hipótese repressiva, Foucault conclui pela proliferação dos discursos sobre o sexo

$23 I d ., I b$.

24 Id., Ibid., p. 24.

$25 I d .$, Ib., p.24.

72 | Cad. Nietzsche, São Paulo, v.I n.35, p. 57-85, 2014. 
enquanto uma espécie de mecânica das próprias incitações da fala mesmo que o "quebrem" ou o "reproduzam". Daí ele concluir afirmando: “O que é próprio das sociedades modernas não é o terem condenado o sexo a permanecer na obscuridade, mas sim o terem devotado a falar dele sempre, valorizando-o como o segredo" ${ }^{26}$. Eis o sentido da suspeita com referência à hipótese discursiva, haja vista que a história dos discursos sobre o sexo não a corrobora pertinentemente.

Na sequência, é apresentada a implantação perversa, que aponta para o século XX como iniciador de heterogeneidades sexuais. Enquanto até o final do século XVIII houve, na avaliação de Foucault, três códigos reguladores das práticas sexuais, quais sejam, o direito canônico, a pastoral cristã e a lei civil, desde o século XIX processou-se a proliferação de sexualidades; cujas regras de práticas propagam-se. Tem-se o exame médico, a investigação psiquiátrica, o relatório pedagógico e os controles familiares com um duplo papel. Por um lado, incitam o prazer através do exercício do poder controlador, fiscalizador e questionador, por outro, o prazer que invade o poder que se exerce. Embora, como aponta Foucault, o objetivo central desse exercício seja aparentemente barrar as sexualidades "errantes" e "improdutivas", ao invés de organizarem fronteiras demarcatórias do possível e do interdito, remetem a, como diz o pensador francês, espirais de poder e $\operatorname{prazer}^{27}$. É nesse meio de exercício de poder sobre os corpos que se configuram as perversões.

Dada o modo como as sexualidades, notadamente heréticas, multiplicaram-se a partir do século XIX e ao surgimento de um dispositivo de controle diferente da lei que, embora interdite, promove a multiplicação das sexualidades, Foucault mostra a necessidade de abandonar a hipótese repressiva, já que as sociedades industriais

26 Id., Ib., p. 36.

27 Cf. FOUCAULT, op. Cit., p. 45. 
modernas, efetivamente, não dão início a uma fase de repressão do sexo: "nunca tantos focos onde estimular a intensidade dos prazeres e a obstinação dos poderes para se disseminarem mais além"28.

Ponto de inflexão importante na exposição do discurso filosófico foucaultiano acerca da sexualidade é descurar essa última e concentrar-se na questão do poder. Assistimos o anúncio, enquanto exercer-se em um processo contínuo de controle e proliferação. Um jogo de alternância e continuidade, no limite, uma luta entre vencedores e vencidos movida pelo exercício contínuo de vencer resistências. O poder não se localiza, ao contrário, se difunde. São redes que se exercem por todos os lados e em todos os momentos. Persistência ao invés de cessação, de pausa temporária ou interrupção abrupta; é continuidade da disputa, do jogo, alternância completa. Daí o conceito de luta que percebemos subjazer ao de poder foucaultiano. Nesse sentido, não podemos deixar de ver o discurso filosófico de Nietzsche atravessar e, porque não dizer, definir o de Foucault. Afinal esse poder que se exerce pode ser compreendido desde a luta preconizada por Nietzsche na base do estabelecimento das significações.

Voltemos a Nietzsche para mostrar o vínculo existente entre o pensador francês e seu mestre, para confirmar nossa hipótese de trabalho de que Foucault, ao silenciar sobre Nietzsche, torna-se mais nietzschiano e, por isso, realiza uma genealogia da moral. A noção de luta (Kampf) tem uma posição privilegiada na filosofia de Nietzsche, desde $A$ disputa de Homero e $O$ nascimento da tragédia até Assim falava Zaratustra e as demais obras que se seguiram. Presente em todos os momentos do discurso de Nietzsche, expressa sempre o movimento, embora com acréscimos e contornos diferenciados ao longo da elaboração da obra do filósofo. Em A disputa de Homero, a luta aparece como disputa (Wetkampf), resgatando o sentido do agon grego que aparece na Ilíada quando do combate entre os

$28 \quad I d ., I b .$, p. 49.

74 I Cad. Nietzsche, São Paulo, v.I n.35, p. 57-85, 2014. 
heróis helenos. Trata-se da disputa que, vista como qualidade, atua estimulando os homens à ação: "julgando como Hesíodo, que aponta uma Eris como má, a saber, aquela que conduz os homens à luta aniquiladora e hostil entre si, e depois enaltece uma outra como boa, aquela que, como ciúme, rancor, inveja, estimula os homens para a ação, mas não para a luta aniquiladora, e sim para a ação da disputa" (CP Prefácio). A partir de Assim falava Zaratustra, a luta passa a ter um caráter mais abrangente enquanto entendida como traço da vida. Todo o existente é visto como um campo de batalha, definido, assim, desde a luta: "Tudo o que ocorre, todo movimento, todo vir-a-ser enquanto determinações de relações de graus e forças, enquanto luta..." (Nachlass/FP 18879 [91]). Determinações de graus e forças é uma forma de exercer-se que vai ao encontro do poder foucaultiano, que se manifesta em todos os segmentos e vias, de todos os modos, que é movimento de disputa contínua. A sexualidade é o objeto que permite desvelar as relações de poder na base de toda manifestação, o que está em questão e se constitui como premente em Foucault é o método que remete ao se exercer do poder. $\mathrm{E}$ isso remonta a Nietzsche sua condição de possibilidade. Eis um traço marcante do nietzschianismo de Foucault e do porquê ele ser, a nosso ver, eminentemente, nietzschiano mesmo em se apropriando de Nietzsche como instrumento de pensamento como método.

Mas voltemos à genealogia da moral foucaultiana em a história da sexualidade, cujo próximo passo é a investigação da scientia sexualis, que se inicia com um balanço dos discursos que se multiplicaram sobre o sexo nos últimos três séculos, marcando que até Freud houve a manutenção do segredo. Tratava-se mais de ocultar aquilo do que se fala do que o manifestar. E isso tanto no discurso dos cientistas quanto dos teóricos, que tem na fala neutra da ciência a mais alta significação, enquanto mostra a subordinação dela a uma moral - veja-se, novamente, o nietzschianismo presente 
e acentuado ${ }^{29}$. Na ótica de Foucault, durante o século XIX, o sexo aponta para sua inscrição em dois registros diferentes, quais sejam, o da biologia da reprodução, que se desenvolve a partir do que ele denomina uma normatividade científica geral, e o da medicina do sexo, cujas regras remetem a origens diversas. Por trás da distinção entre elas estaria em uma a vontade de saber, enquanto, em outra, a vontade de não-saber. Todavia, mesmo o calar remete à vontade de verdade:

O importante é que o sexo não tenha sido somente objeto de sensação e de prazer, de lei ou de interdição, mas também de verdade e falsidade, que a verdade do sexo tenha-se tornado coisa essencial, útil ou perigosa, preciosa ou temida; em suma, que o sexo tenha sido constituído em objeto de verdade ${ }^{30}$.

Eis outro tributo e apropriação de Nietzsche, pois Foucault vale-se do conceito de vontade de verdade nietzschiano. Vejamos como em Sobre verdade e mentira no sentido extra-moral, Nietzsche faz alusão direta ao impulso à verdade e ao pacto de sua origem, da oposição entre verdade e mentira e da postulação das leis da verdade, mostrando, ser ela proveniente de uma necessidade de impedir a guerra de todos contra todos, em suma, uma mera convenção, em Para além de bem e mal e nos Fragmentos póstumos posteriores, não deixará de vê-la como acordo de paz, mas perceberá sua importância para a existência humana: "A verdade é este tipo de erro sem o qual uma certa espécie de seres viventes não poderia viver"(Nachlass/FP 34 [253]). Mas na Gaia ciência mostrará de

29 Vejamos como Nietzsche subordina os discursos filosóficos à moral que professam. Mas considere-se que embora se trate de mostrar o vínculo, nessa passagem, entre filosofia e moral, a mesma se efetiva com relação a todos os discursos: "No filósofo, pelo contrário, absolutamente nada é impessoal; e particularmente a sua moral dá um decisivo testemunho de quem ele é..." (JGB/BM 6, KSA 5.20).

30 FOUCAULT, M. História da sexualidade: a vontade de saber. Trad. Maria Thereza Albuquerque e J. A. Albuquerque, 15 ed. Rio de Janeiro: Graal, 2003, p. 56. 
modo iniludível a vinculação da vontade de verdade à moral: "Pois também desta última maneira poderia ser interpretada a vontade de verdade: pressuposto que sob a generalização 'eu não quero enganar' esteja incluído também o caso particular 'eu não quero me enganar" (FW/GC 344, KSA 3.574-7). Imbricar verdade e moral é outro feito inusitado que mostra as implicação do discurso filosófico mais com a moralidade e a exigência de não se deixar enganar do que com o conhecimento e a objetividade da referida verdade. Como não relacionar os conceitos de Foucault aos de Nietzsche? Como não afirmar o nietzschianismo inscrito no discurso filosófico do pensador francês?

Na sequência, Foucault apresenta os dois grandes procedimentos que produziram a verdade sobre o sexo. São eles as sociedades que adquiriram uma ars erótica e aquelas que praticaram uma scientia sexualis, essa última pertencente à nossa civilização. A diferença existente entre elas é que a primeira verdade se produz desde o prazer enquanto prática, isto é, determinado pela intensidade, qualidade e duração; sempre envolto em um segredo gerador da própria manutenção, que se efetiva quando ele é transmitido. Oposta à iniciação e ao segredo da ars erótica, a segunda remete à prática da confissão. A produção da verdade passa pela confissão desde o Concílio de Latrão, ao regulamentar em 1215 o sacramento da penitência, desenvolvendo-se e inscrevendo-se nos mais variados meios na sociedade Ocidental. Daí Foucault afirmar ter se tornado o homem ocidental "um animal confidente", pois, para ele: "A confissão da verdade se inscreveu no cerne dos procedimentos de individualização pelo poder"31. Daí Foucault mostrar o quanto a verdade sobre o sexo está ligada a essa forma discursiva, em que há uma coincidência entre os sujeitos da fala e do enunciado, entre o falar e o que se fala, articulando o saber à confidência: “A confissão

31 FOUCAULT, op. cit., p. 58. 
foi, e permanece ainda hoje, a matriz geral que rege a produção do discurso verdadeiro sobre o sexo" ${ }^{32}$.

Ponto importante da história da sexualidade de Foucault foi mostrar que, através "de uma codificação clínica do "fazer falar", efetivado na combinatória da confissão com o exame; por meio "do postulado de uma causalidade geral e difusa", cuja sustentação está na dotação do sexo de uma causalidade inesgotável; mediante o "princípio de uma latência intrínseca à sexualidade", que faz o sexo funcionar como obscuridade; por intermédio "do método de interpretação" que legitima a fala naquele que ouve; e, por fim, "através da medicalização dos efeitos da confissão" por meio de operações terapêuticas, constituíram os procedimentos da vontade de saber que fizeram a confissão funcionar em formas científicas. Em vista disso, a sociedade ocidental instaurar uma scientia sexualis, rompendo completamente com a ars erótica. Em suma, a confissão gerou e produziu a verdade do sexo, configurando-se como dispositivo que faz aparecer a sexualidade como "verdade do sexo e dos prazeres", que, como diz Foucault, "é o correlato dessa prática discursiva desenvolvida lentamente, que é a scientia sexualis" "33. Por isso, fazer a história da sexualidade é, simultaneamente, no discurso filosófico foucaultiano, fazer a história dos discursos. Somente desse modo, é possível precisar as estratégias de poder imanentes à vontade de saber.

Continuando a história da sexualidade, Foucault vai mostrar o que está é e como esteve em jogo desde o princípio de sua genealogia. Aquilo que a atravessa e a define, que marca um modo de proceder objetivado no discurso filosófico de a vontade de saber e que se denomina uma analítica do poder. Nesse momento, o pensador francês encaminha-se para a questão do método, o que nos permitirá uma aproximação direta com Nietzsche, pois, assim

32 Id., Ib., p. 62.

33 Id., Ib., p. 67.

78 I Cad. Nietzsche, São Paulo, v.I n.35, p. 57-85, 2014. 
como o pensador alemão, Foucault rejeita compreender o poder como representação, mesmo que se refira à jurídico-discursiva, podemos estendê-la a todas as formas de representação do poder, que se configuraram desde a recusa da compreensão dele como um exercer-se nas variadas esferas ao invés de ser antecedido por um procedimento que o processa e torna eficaz.

Encontramos, novamente, a ressonância da filosofia de Nietzsche na filosofia de Foucault, quando o último deixa explícita a diferença existente entre poder como constituição, que remete ao forte, senhor e sua moral nobre e o poder como representação, expressão do fraco e sua moral de escravos, que realiza a inversão dos valores nobre-aristocráticos, através da associação viabilizadora da representação de si como poderoso e da tentativa de aniquilar o adversário, presentes em segmentos políticos históricos, dentre eles, o Terceiro Reich, via latência do extermínio do outro. Sob esse aspecto, o poder de Foucault coincide com a força em Nietzsche e o poder como representação vai ao encontro do paralogismo, em que a força aparece separada do que ela pode. Mas o autor de Assim falava Zaratustra deixa claro que, a distinção entre a força e seus efeitos manifesta-se em uma ficção que tem por finalidade possibilitar o julgamento da força, à medida que suas manifestações passam a ser vistas como realizadas por um sujeito de forma livre e espontânea. A sedução da linguagem determina, segundo Nietzsche, essa separação, a partir do condicionamento do ato a uma causa eficiente. Todo esse mecanismo construído tem por objetivo incutir na força uma culpa pelas suas manifestações espontâneas. Desse modo, o efeito, manifestação da força, estaria condicionado por um sujeito livre que poderia ou não ter agido de determinada forma. $\mathrm{O}$ impotente se utiliza da sedução da linguagem para sustentar que o forte é fraco ou, como na metáfora utilizada por Nietzsche, que "a ave de rapina pode ser cordeiro". Dessa maneira, poderiam pedir contas à ave de rapina por ela ser ave de rapina. Vemos o poder em Foucault, exigindo a completa distinção entre o exercer-se dele e o ser representado por ele. Por isso, Foucault pensa: “o sexo sem a lei 
e o poder sem o rei" ${ }^{34}$, como apresentaremos sequencialmente na exposição acerca do método, assim como a apropriação do conceito de força em Nietzsche como correlato do de poder em Foucault.

Na parte concernente ao método, coube a Foucault, justamente, especificar em que sentido utiliza a palavra poder, para excluir de seu campo de abrangência tanto o conjunto de instituições que socialmente detém o poder de mando e regulamentação entre os membros de uma coletividade instituída e, nesse sentido, é identificado com o Estado, quanto o poder como regra ou sistema de dominação exercido por um elemento específico. Não se trata de localizar ou situar o poder em um campo ou horizonte determinado e delimitado, mas ao contrário, perceber que se trata de uma disseminação contínua, que está imersa em todo e qualquer segmento. Daí a remessa feita pelo filósofo francês do sentido de poder ao de multiplicidade de correlações de forças, que se exercem, efetivam, lutam, jogam e constituem organizações.

As instituições, o Estado, o elemento específico são formas terminais do poder, porque resultam, enquanto corpo que gesta, das estratégias que tem proveniência na luta e no jogo da multiplicidade de forças. Nas palavras de Foucault: "o poder está em toda parte; não porque englobe tudo e sim porque provém de todos os lugares" "35. Sendo assim, é impossível adquiri-lo, compartilha-lo ou mesmo tomá-lo, pois o poder, sob essa ótica, não está jamais localizado. Todas as relações, das econômicas às de conhecimento, pressupões relações de poder que lhes são imanentes enquanto produtoras das demais. Outra especificidade do conceito foucaultiano de poder é compreendê-lo como, simultaneamente, relações intencionais e não subjetivas, porque, no primeiro caso, remetem a uma mirada do poder que se exerce e, no segundo, em função do excluir uma instância outra, um sujeito, que possa explicá-lo

34 FOUCAULT, op. cit., p. 87.

35 Id., Ib., p. 89.

80 | Cad. Nietzsche, São Paulo, v.I n.35, p. 57-85, 2014. 
externamente. Não há, nesse caso, causalidade ou subjetividade às quais se possam remeter esse conceito. De modo diverso da exterioridade explicativa é a imanência estrita das lutas e jogos de forças que permite compreender o conceito de poder em Foucault. Afinal, para ele: "É nesse campo de correlações de força que se deve tentar analisar os mecanismos de poder"36.

A nosso ver, poderíamos substituir o conceito de poder foucaultiano, pelo de impulso, força ou vontade de potência de Nietzsche, uma vez que há uma similaridade notável entre ambas as noções. Em um fragmento póstumo de 1886-1887, Nietzsche comenta: “o indivíduo é um campo de batalha de suas diferentes partes (para a alimentação, espaço, etc.): sua evolução está ligada a um vencer, à predominância de determinadas partes, ao perecimento, à transformação de órgãos de outras determinadas partes" (7 [25] do final de 1886/primavera de 1887). Essa ligação do vivente ao vencer faz com que a estrutura hierárquica sofra alterações, já que a disputa constante determina, a cada momento, vencedores e vencidos. $\mathrm{O}$ vencedor suporta o peso do vencido, mas pode ser vencido em uma disputa subsequente. A vida atua sempre explorando, dominando, assenhorando-se. A vida, em Nietzsche, é vontade de potência que se exerce, no mesmo sentido do poder de Foucault. A força é o exercer-se, não podendo, por conseguinte, ser separada dele, salvo por artifícios da linguagem. O efetivar-se define os conceitos, sustenta sua produção e confere ao mundo uma efetividade instituinte, já que a pluralidade de forças, de vontades de potência introduzem perspectivas e, assim, assentam o efetivo.

Os discursos sobre o sexo em Foucault imergem das relações de poder enquanto múltiplas e móveis. Em vista disso, ele o analisa não por uma remessa à repressão ou à lei, mas em termos estritos de poder, no sentido, sempre, de campos de forças em combate, na mesma acepção de Nietzsche. É isso que o leva, com relação

$36 \quad I d ., I b .$, p. 92. 
à genealogia da moral empreendida em a história da sexualidade, a estabelecer quatro regras metodológicas, entendidas mais como prescrições da prudência. A primeira delas é a Regra da imanência que se configura enquanto remete o conhecimento acerca da sexualidade a uma constituição que vem a ser a partir de relações de poder. "Se a sexualidade se constitui como domínio a conhecer, foi a partir de relações de poder que a instituíram como objeto possível" ${ }^{37}$. A segunda, Regra das variações contínuas remete justamente ao esquema que as correlações de forças impõem em termos de modificações constantes no jogo. Entre distribuições de poder e apropriações de saber processam-se, o que o filosofo francês denomina, cortes instantâneos em processos. "As relações de poder-saber não são formas dadas de repartição, são "matrizes de transformações" " A Regra do duplo condicionamento, terceira, remete aos encadeamentos sucessivos entre as forças em relação no palco da disputa, em que não há homogeneidade ou descontinuidade: "ao contrário, deve-se pensar em duplo condicionamento, de uma estratégia, através da especificidade das táticas possíveis e, das táticas, pelo invólucro estratégico que as faz funcionar". A última prescrição, Regra de polivalência tática dos discursos acentua o papel dos discursos que articulam o poder e o saber. $\mathrm{O}$ discurso aparece em Foucault enquanto sitio da multiplicidade de elementos discursivos, sem uniformidade ou estabilidade.

A história da sexualidade é o objeto da investigação genealógica empreendida por Foucault em "a vontade de saber" enquanto genealogia da moral dele, pois se trata de, a partir dos documentos do passado, retraçar a constituição do saber sobre o sexo desde as relações de poder e, no embate, de o saber produzido gerar novas relações de poder. Desse modo, há em Foucault uma implicação recíproca entre saber e poder que se objetiva nos discursos

37 FOUCAULT, op. cit., p. 93.

38 Id., Ib., p. 94.

82 I Cad. Nietzsche, São Paulo, v.I n.35, p. 57-85, 2014. 
políticos, econômicos e da sexualidade. Analisar genealogicamente a sexualidade é precisar essas relações de poder-saber no decurso da história, apontando para o elemento fluido delas e para as estratégias que propagam os seus dispositivos. Dentre elas, Foucault cita: a Histerização do corpo da mulher, enquanto processo mediante o qual o corpo da mulher foi analisado como corpo sexualizado e aparece como efeito de uma patologia intrínseca que coloca o corpo feminino na ordem das práticas médicas; posto ainda em relação com o corpo social, o corpo familiar e a vida das crianças. A Pedagogização do sexo das crianças em que a criança é posta como se dedicando a uma atividade sexual; a Socialização das condutas de procriação, que se configurou através do controle da fecundação dos casais; a Psiquiatrização do prazer perverso, quando o próprio instinto sexual é isolado enquanto biológico e psíquico a mercê de anomalias e requerente de tecnologias corretivas. $\mathrm{O}$ ponto alto do livro está, no item domínio, em mostrar que todas as estratégias, da histerização do corpo da mulher à psquiatrização do prazer perverso não são uma forma de inibir, controlar ou suspender a sexualidade, mas, de modo bem diverso, através das estratégias de poder-saber que ela se produz, isto é, surge como sexualidade.

$\mathrm{O}$ poder é uma relação de forças diversa de uma substância e sem possibilidade de localização. Não é uma qualidade inerente a alguns e ausente em outros, mas uma rede presente em todas as instâncias. $\mathrm{O}$ saber envolve objetos, conceitos, adesões a teorias e congêneres, mas é, ao mesmo tempo, resultado de determinadas relações de poder que o produzem como saber e esse saber produzido gera novas relações de poder, confirmando a existência de uma implicação recíproca entre poder e saber em termos de constituição de um e de outro no decurso da história como palco das forças em luta constante. A história da sexualidade configura a genealogia da moral foucaultiana em que silencia o intérprete para vir à cena o filósofo e, nesse sentido, vemos por que Foucault é nietzschiano ao se apropriar dos conceitos de Nietzsche e realizar a investigação de poder e saber no volume I da História da sexualidade, consistindo 
o procedimento genealógico e os conceitos nietzchianos em instrumentos para pensar as questões foucaultinas, cujo método é uma apropriação filosófica de conceitos vertidos para o discurso filosófico daquele que os emprega, isto é, de Foucault.

\begin{abstract}
In this article we will analyze Foucault texts about Nietzsche: "Nietzsche, Freud and Marx" along with "Nietzsche, the genealogy and the history" as well as the philosopher texts about the History of sexuality, volume I, in order to show that in the first case, the French thinker seeks to attain the conceptual precision of the nietzschean reports starting from a intratextual reading, and in the second case, proceeds with the treatment of Nietzsche as an instrument of thought, making so that Foucault appropriates of Nietzsche to think his own philosophical questions.
\end{abstract}

Keywords: Nietzsche - methodology - genealogy - history - sexuality

\title{
referências bibliográficas
}

FOUCAULT, M. História da sexualidade 1. Rio de Janeiro: Graal, 1985. . História da sexualidade 3: O cuidado de si. Rio de Janeiro: Graal, 1985. . História da sexualidade 2: o uso dos prazeres. Rio de Janeiro: Jorge Zahar, 1994. . Resumo dos cursos de college de france 1970-1982. Rio de Janeiro: Graal, 1994. . O homem e o discurso. Rio de Janeiro: Tempo Brasileiro, 1994. . A mulher e os rapazes. Rio de Janeiro: Paz e Terra, 1997.

. Ditos \& escritos. Problematização do sujeito: psicologia, psiquiatria e psicanálise.

V Vol. Rio de Janeiro: Forense Universitária, 1999.

. O que é a crítica? (crítica ou aufklarung). Trad. Antônio C. Galdino. In: BIROLI, Flávia; ALVAREZ, Marcos César (orgs.). Michel Foucault: histórias e destinos de um pensamento. Cadernos da Faculdade de Filosofia e Ciências (FFC - UNESP), Vol.9, n.1 . Marília: Unesp-Marília-Publicações, 2000.

. Microfísica do poder. Rio de Janeiro: Graal, 2000.

- Vigiar e punir. Nascimento da Prisão. Trad. Raquel Ramalhete. 23a, Rio de Janeiro: Vozes, 2000.

. Os anormais. São Paulo: Martins Fontes, 2001.

84 I Cad. Nietzsche, São Paulo, v.I n.35, p. 57-85, 2014. 
. A verdade e as formas jurídicas. São Paulo: Nau Editora, 2002. . Em defesa da sociedade. São Paulo: Martins Fontes, 2002.

. Isto não é um cachimbo. Tradução Jorge Coli. 3.ed. Rio de Janeiro: Paz e terra, 2002.

. The Birth of the clinic. ROUTLEDG - USA, 2003.

- A hermenêutica do sujeito. Trad. Márcio Alves da Fonseca e Salma Tannus Muchail. 1a ed. São Paulo: Martins Fontes, 2004.

. A ordem do discurso. Aula Inaugural no Collège de France, Pronunciada em 2 de Dezembro de 1970. Leituras Filosóficas. 11a São Paulo: Loyola, 2004.

NIETZSCHE, F. Sämtliche Werke - Kritische Studienausgabe, edição organizada por Giorgio Colli e Mazzino Montinari. Berlim: Walter de Gruyter \& Co., 1967/1978. $15 \mathrm{vol}$.

Obras Incompletas, coleção "Os Pensadores”. Trad. Rubens Rodrigues Torres Filho, São Paulo: Abril Cultural, 1978.

Para além de bem e mal. Trad. Paulo César Souza. São Paulo: Companhia das Letras, 1992.

Ecce homo. Trad. Paulo César Souza. São Paulo: Companhia das Letras, 1995.

Genealogia da Moral. Trad. Paulo César Souza. São Paulo: Brasiliense, 1987.

Artigo recebido para publicação em 10/03/2014.

Artigo aceito para publicação em 08/04/2014.

Cad. Nietzsche, São Paulo, v.I n.35, p. 57-85, 2014. | $\mathbf{8 5}$ 